\title{
PRELIMINARY REPORT ON THE GROUND-WATER SUPPLY OF MIMBRES VALLEY, NEW MEXICO
}

\author{
By Walter N. White
}

\section{GENERAL FEATURES OF MIMBRES VALLEY}

This report relates to the supply of water that occurs below the surface of the Mimbres Valley, an extensive plain in the southwestern part of New Mexico, which may be defined as the lowland part of the potential drainage basin of the Mimbres River. (See pl. 1.) Thus defined, the Mimbres 'Valley, north of the Mexican border, nearly coincides with Luna County and covers an area of about 2,500 square miles. North of this great plain is an extensive upland area which includes the Mimbres, Black, and Pinos Altos Mountains and the Cooks Range. The Mimbres River and its principal tributaries rise in these mountains and discharge southward upon the lowland plain. They are all ephemeral streams except for a few stretches in the mountains that are fed by springs.

The mountains consist of hard rocks of many kinds that have a wide range in age and a complex structure. The lowland plain is in most places underlain to considerable depths by clay, sand, and gravel that have been derived from the rock waste washed out from the mountains. The plain is diversified by numerous mountains and buttes, which are projecting parts of rock masses partly buried by the valley fill. The porous beds of the valley fill form a great underground reservoir; which contains a large supply of water that has been contributed during a long period by the Mimbres and other mountain streams. Over a large part of the Mimbres Valley the ground water stands within 100 feet of the surface, and in a few relatively small tracts the depth to the water table is less than 25 feet.

The city of Deming, which is estimated to have a population of about 3,500, is near the center of the Mimbres Valley. It is on the main line of the Southern Pacific Railroad and on the branch line of the Atchison, Topeka \& Santa Fe Railway that leads to Silver City. It is also on a well-improved east-west highway, which is extensively used in transcontinental travel, especially in winter. The valley is utilized for cattle ranching and irrigation farming. The precipitation, which averages about 10 inches a year and occurs chiefly in rainstorms during the summer, is not sufficient to permit farming 
without irrigation, but in favorable years it produces a good growth of grass on the range. Irrigation is accomplished chiefly with water pumped from wells.

\section{HISTORY OF IRRIGATION WITH GROUND WATER}

Irrigation by pumping from wells began in the Mimbres Valley during the period 1908 to 1911 . About 1912 there was a rapid expansion in pumping development, which at first had been more or less of an experiment, and, according to Darton, ${ }^{1}$ by 1914 nearly 200 pumping plants were installed or under erection. These pumping plants were spaced over a large area, extending from Deming southward 33 miles to the Mexican border, eastward about 15 miles to Miesse, and westward about 7 miles to the locality of Red Mountain. (See pl. 1.)

A large part of the development was undertaken by men who had practically no experience in the operation of pumping plants, many knew little or nothing about irrigation of any.kind, and some had never farmed before. Little attention was given by these inexperienced men to economy in pumping-plant installation and operation or to the question whether the soils of the lands placed under irrigation were adapted for producing the crops irrigated. As a result operating costs exceeded crop returns, and many of the pumpingplant owners became discouraged and abandoned their farms. The decline in pumping activity was almost as rapid as its rise, and, according to the best information available, by 1918 or 1919 only about 25 pumping plants were in operation. The slump continued for several years. About 1923 or 1924 a revival in development began, and there has been a gradual but steady increase ever since. There are now 116 pumping plants in operation. This number includes the railroad, smelter, sanitarium, county, and city plants, all located at or near Deming, but does not include small outfits used for stock or family supply. About 6,000 acres is under irrigation with pumped water. This year there has been a net gain of 9 in the number of plants operated and an increase of 500 acres in the irrigated area. The present pumping-plant owners with few exceptions are good farmers. The lands are well cultivated, and good judgment is shown in the choice of crops and in the methods used in irrigating them. The pumping plants are operated with fair efficiency, although in some the machinery is in poor condition. As a result most of the farmers are making money.

\section{PURPOSE AND SCOPE OF PRESENT INVESTIGATION}

The recent success of irrigation has led the landowners in the valley and the business men of Deming to believe that the ground-

\footnotetext{
1 Darton, N. H., Geology and underground water of Luna County, N. Mex.: U. S. Geol. Survey Bull. 618, p. $122,1916$.
} 
water resources of the valley should be developed to the safe limit of the available supply. It is recognized that overdevelopment would be fatal to the best interests of the community and that future expansion in pumping activities should be guided by as adequate information as it is possible to obtain concerning the extent of this resource.

About two years ago the Deming Chamber of Commerce, through the influence of several of its most public-spirited members, requested Herbert W. Yeo, State engineer of New Mexico, to make plans for a survey of the valley that would lead to a quantitative estimate of the water supply. At his request, Albert G. Fiedler, a hydraulic engineer in the United States Geological Survey, made a preliminary study of the problem in August, 1927. Shortly thereafter Mr. Fiedler incorporated his findings in a report, ${ }^{2}$ copies of which were transmitted to the State engineer and to the Deming Chamber of Commerce. The report contained a summary of the information then available that had a bearing on the problem and concluded with the estimate that a proper investigation would require the services of a geologist and engineer equivalent to the time of one man for a period of about two years.

Late in September, 1927, Mr. Fiedler revisited the valley and selected 25 observation wells, on five of which automatic water-stage recorders were installed. Under the direction of the State engineer observations of water levels in these wells were made at frequent intervals during the fall, winter, and spring of 1927-28. In the meantime arrangements were made through the State engineer to have the desired investigation made by the United States Geological Survey, under the direction of Oscar E. Meinzer, geologist in charge of the division of ground water. The writer was assigned to the project and began field work in July, 1928. More than a year has since elapsed, and it is now deemed advisable to submit a preliminary report giving some of the results. The investigation is by no means completed, however, and therefore only tentative conclusions can be drawn.

The investigation is chiefly concerned with the quantity of ground water available, the practical problem being to determine how much water can be pumped without seriously depleting the underground reservoir and lowering the water table below the limits of the economic pumping lift.

An underground reservoir is not unlike a surface reservoir. If inflow exceeds withdrawal the water level in the reservoir rises, but if withdrawal is greater than inflow the level declines. In an underground reservoir, especially if it is of great size, the withdrawal may for a time exceed the average annual recharge without causing serious

\footnotetext{
${ }^{2}$ Fiedler, A. G., Report on a reconnaissance of the ground-water area of the Mimbres Valley, Luna County, N. Mex.: New Mexico State Engineer Eighth Bienn. Rept., pp. 159-171, 1928.
} 
trouble, but eventually a considerable lowering of the water level may result and it may become necessary to restrict pumping to an amount no greater than the recharge.

Fluctuations in ground-water levels afford a valuable clue as to the amount of the annual recharge and as to whether discharge is less, equal to, or in excess of recharge. An important part of the investigation therefore is being devoted to studies of seasonal and yearly changes in ground-water levels. Regular observations of water-level fluctuations are being made on about 150 wells, including 23 of the wells selected by Mr. Fiedler (two wells selected by Mr. Fiedler have become dry). These wells are spaced to cover a wide area from Deming north to the mountains and south to the Mexican border. Six of the wells located at critical points are equipped with automatic water-stage recorders, which are constructed to give continuous graphic records of all changes in water level. The other observation wells are measured monthly with a steel tape.

It is important to know how and where the water reaches the underground reservoir. Studies have therefore been made of the facilities for the intake of ground water in different parts of the valley and surrounding areas. The Mimbres River is the largest contributor to the ground-water supply, and hence current-meter measurements have been made to determine the rate of seepage losses from different sections of this stream. One set of such measurements has also been made on Lampbright Draw. Elsewhere the areas of possible intake have been studied by observing the materials underlying the surface and making tests of these materials to determine their capacity for quick absorption of water during the comparatively brief periods that surface flows exist. Much depends upon the capacity of the water-bearing beds to conduct ground water from areas of intake to the pumped areas. Considerable time, therefore, has been devoted to studies of the permeability of the water-bearing formations, the gradient of the water table, and finally the rate of ground-water movement. Measurements of the underflow beneath the bed of the Mimbres River have been made at two points in the cross section at the dam site 30 miles north of Deming, and further work of this sort will be undertaken in the summer of 1930 .

\section{SOURCE OF THE GROUND WATER}

The volume of water stored in the beds of sand and gravel that underlie the Mimbres Valley is very great-probably several times the volume annually discharged by the Rio Grande at the Elephant Butte Reservoir. Where does the water come from? This question can be definitely answered. A contour map of the water table has been prepared from data obtained by carrying lines of levels to about 200 wells in which the depth to the water level was measured. (This map will be submitted with the final report.) It shows that practi- 
cally everywhere under the valley the water table slopes from northwest to southeast. As ground water, following the laws of hydraulics, moves in the direction of the hydraulic gradient or slope of the water table, the map shows that the ground water is coming chiefly from the upper end of the valley. The Mimbres River and its tributaries, the chief of which is San Vicente Arroyo, enter the valley there and contribute the greater part of the inflow of surface water into the valley. These streams shrink rapidly upon reaching the plain and in times of low flow disappear within a short distance after leaving the bedrock of their mountain courses. At the upper end of the valley the water table slopes away from the river as well as in the direction of the surface slope, and wells near the stream display a rapid and pronounced rise after a run of water of fair magnitude and length. From these facts and others discussed later in this report it is concluded that a very large part of the supply comes from the main Mimbres River. Lesser quantities are contributed by San Vicente Arroyo and its tributaries. Comparatively little water is contributed by run-off from the Florida Mountains or from the low mountains and hills on the west side of the valley. The run-off from the Cooks Range is a factor of some importance, because storm waters from the northwest slopes of the range discharge into the Mimbres River and later a part of this run-off reaches the ground water through the sand and gravel of the river bed. Run-off from the south and southeast slopes of the range also provides ground-water recharge, but the amount is believed to be small. Northward from Spalding the surface gradients are steep and there is considerable run-off from precipitation on the valley floor itself, which reaches the Mimbres River or its tributaries and later seeps underground through the river bed. Moreover, large areas in that part of the valley are underlain by coarse gravel through which some ground-water recharge may take place directly from rainfall, although the gravel is nearly everywhere cemented or partly cemented, and the amount of such recharge is probably small. It may safely be stated that southward from Spalding practically no recharge takes place from precipitation on the valley floor and the area of ground-water intake is largely limited to the bed of the Mimbres River.

The opinion has been expressed by several residents of Deming that the ground water of the Mimbres Valley comes from the headwaters of the Rio Grande in Colorado or from some other distant mountain area. This is believed to be impossible. Hundreds of miles of high plateau and mountainous country, underlain by dense rocks through which water moves very slowly if at all, lies between the Mimbres Valley and those distant regions. Even if it were possible for water to move great distances through rocks of this character the amount that could percolate would be exceedingly small. 


\section{STREAM DISCHARGE AND UNDERELOW}

The State engineer's office and the United States Geological Survey have together maintained gaging stations on the Mimbres River near Faywood and near Mimbres and on Lampbright Draw and Cameron Creek, two of the larger tributaries of San Vicente Arroyo, for periods of varying lengths during the last 20 years or so. The stations on Lampbright Draw and Cameron Creek have been discontinued, but those on the Mimbres River are still in operation.

Summary of records of discharge of Mimbres River, Lampbright Draw, and Cameron Creek

[Compiled from published records of the State engineer and United States Geological Survey]

\begin{tabular}{|c|c|c|c|c|c|c|}
\hline \multirow{2}{*}{ Stream } & \multirow{2}{*}{$\begin{array}{c}\text { Drain- } \\
\text { age area } \\
\text { above } \\
\text { station } \\
\text { (square } \\
\text { miles) }\end{array}$} & \multirow{2}{*}{$\begin{array}{l}\text { Period } \\
\text { of record }\end{array}$} & \multirow{2}{*}{$\begin{array}{l}\text { Length } \\
\text { of record } \\
\text { (years) }\end{array}$} & \multicolumn{3}{|c|}{$\begin{array}{l}\text { Average annual discharge (acre- } \\
\text { feet) }\end{array}$} \\
\hline & & & & $\begin{array}{c}\text { Full } \\
\text { period }\end{array}$ & $1914-16$ & $\begin{array}{l}\text { Rest of } \\
\text { period }\end{array}$ \\
\hline Mimbres River a & 450 & $\left\{\begin{array}{l}1908-1910 \\
1912-1928\end{array}\right\}$ & 20 & 16,400 & 54,500 & 9,700 \\
\hline Lampbright Draw ........... & 30 & $1913-1922$ & 10 & 1,300 & 3,000 & 400 \\
\hline Cameron Creek....... & 20 & $\left\{\begin{array}{c}1907-1910 \\
1914\end{array}\right\}$ & 5 & b 1,600 & 6,000 & 500 \\
\hline
\end{tabular}

a Faywood gaging station.

$b$ Discharge in 1914.

The writer has not examined the sites of the discontinued stations on Lampbright Draw and Cameron Creek. At Faywood station on the Mimbres, where the 20-year record was obtained, the river bed is sandy and shifts considerably with every large flood. Under such conditions the computation of stream discharge from records of gage height is subject to some inaccuracy, particularly during periods of very large or very small discharge. However, the figures for average discharge given in the table were prepared by engineers of experience in the interpretation of stream flow in shifting channels and are assumed to be accurate within reasonable limits.

The outstanding feature of the performance of these streams is the proportionately great discharge that occurred during the wet years 1914 to 1916. The total discharge of the Mimbres River during these three years amounted to about 164,000 acre-feet, whereas the total during the remaining 17 years of record amounted to only about 165,000 acre-feet.

The figures in the table give the surface discharge but do not include the underflow, the amount of which, for the Mimbres River, is popularly believed to be large. Considerable attention was given to this question in the investigation.

About 1,000 feet above the Faywood gaging station the river cuts across a ridge of highly resistant and relatively impermeable igneous rock. At this point the width of the channel between opposite 


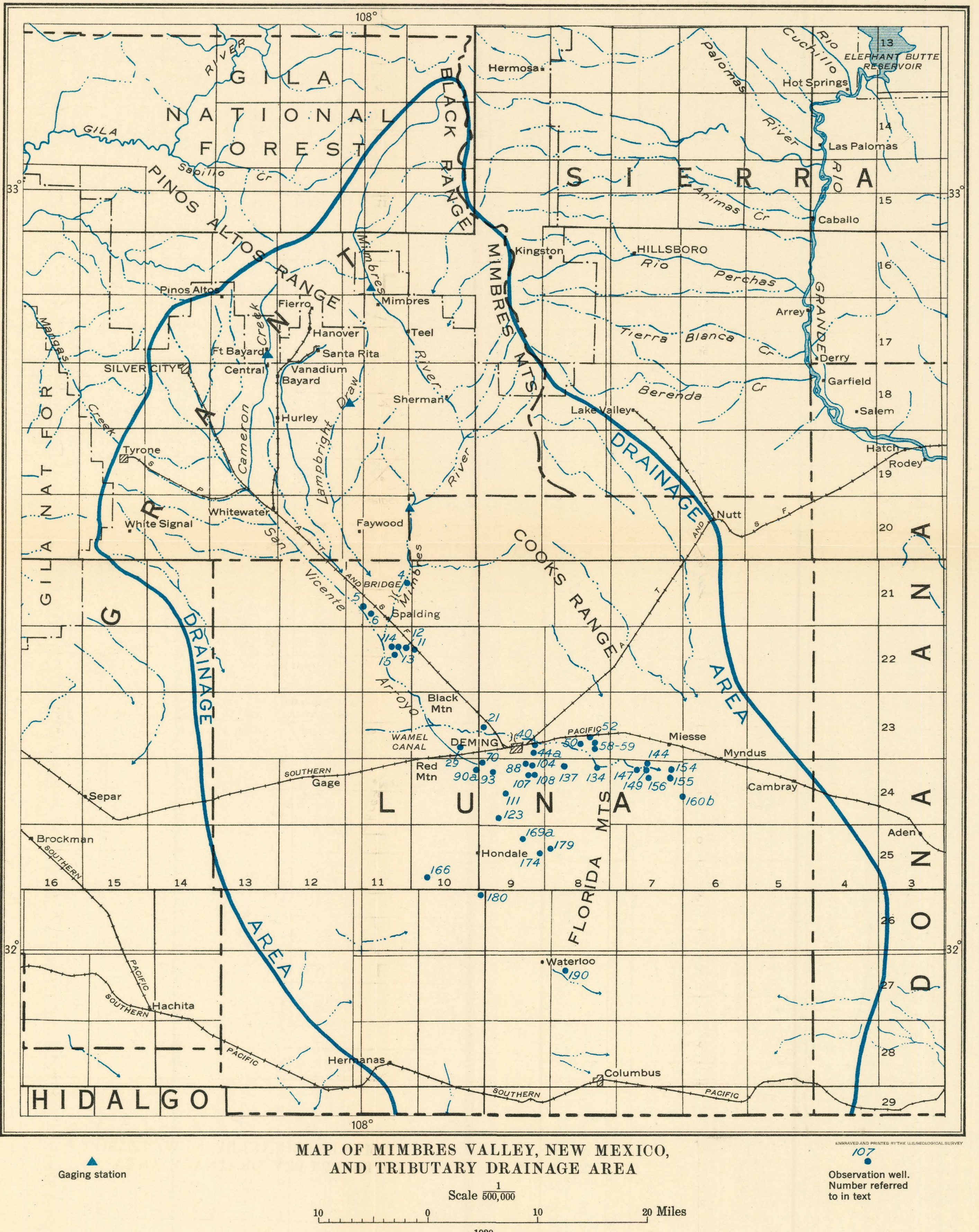


rock walls is only 750 feet, and depths to the bedrock beneath the channel as disclosed by exploratory drilling are comparatively small. This is the site on which it has been proposed to construct a dam to conserve the flood and waste waters of the Mimbres.

As a result of the constriction of the valley at this point, both in width and in depth, much of the underflow is brought to the surface as springs, the discharge from which flows down past the gaging station and is taken into account in the gaging records. Some of the underflow continues underground through the gravel overlying the crest of the rock barrier. Measurements of this underflow were undertaken according to Slichter's methods with some variations. Four well points were driven into the gravel in ground plan about as follows:

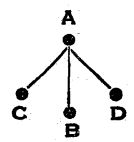

In this arrangement $A$ is the upstream well; $B, C$, and $D$ were driven 4 feet from $A$ in a downstream direction, B directly downstream and $\mathrm{C}$ and D respectively 2 feet to the right and 2 feet to the left. The rate of underflow was determined by introducing salt water into well $A$ and then recording the time interval required for the salt to reach one of the downstream wells, a silver nitrate solution being used to detect the arrival of the salt in the lower well. The work was attended by considerable difficulty. The river sand and gravel at the dam site were interspersed with boulders, and the points could be driven only 2 or 3 feet below the water table. The first wells were put down early in August and before the experiment could be completed were caught by a flood on August 9 and filled with mud and silt. The experimental work was renewed early in September, and eventually determinations were made showing velocities of 26 and 29 feet a day, respectively, at two points in the cross section, one about 200 feet from the east bank and the other about 250 feet from the west bank.

The exploratory drilling at the dam site was done many years ago, and no accurate figures as to the depths to bedrock have yet been found by the writer. According to report the average depth was found to be about 20 feet. On this basis the gravel along the line between rock outcrops would have a cross-section area of 15,000 square feet. Practically everywhere that underflow measurements have been made it has been found that the velocity of the underflow decreased with the depth below the bed of the stream.

If it is to be assumed that the underflow at the Mimbres dam site does not decrease with the depth of the gravel, that the average of the two observed rates of underflow (27.5 feet a day) represents the 
average velocity in the entire cross section, and that the effective porosity of the gravels is 25 per cent, this total underflow amounts to 1.17 second-feet, or 850 acre-feet a year. In the table below these figures are compared with the results of several well-known underflow measurements and estimates made by Slichter on other streams.

Comparison of tentative estimate of underflow of Mimbres River with underflow measurements on other streams made by Slichter

\begin{tabular}{|c|c|c|c|c|}
\hline Stream & Locality & $\begin{array}{l}\text { Area of } \\
\text { cross } \\
\text { section } \\
\text { (square } \\
\text { feet) }\end{array}$ & $\begin{array}{c}\text { Velocity } \\
\text { (feet per } \\
\text { day) }\end{array}$ & $\begin{array}{c}\text { Total } \\
\text { underflow } \\
\text { (second- } \\
\text { feet) }\end{array}$ \\
\hline $\begin{array}{l}\text { Mimbres River. } \\
\text { Rio Grande } \\
\text { Mohave River. } \\
\text { Arkansas River. }\end{array}$ & $\begin{array}{l}\text { Near Faywood gaging station...... } \\
\text { Near El Paso, Tex } \\
\text { Near Victorville, Calif. } \\
\text { Near Garden City, Kans }\end{array}$ & $\begin{array}{r}15,000 \\
11,200 \\
4,160 \\
75,000\end{array}$ & $\begin{array}{l}27.5 \\
3 \\
50 \\
10\end{array}$ & $\begin{array}{l}1.17 \\
.13 \\
1-9\end{array}$ \\
\hline
\end{tabular}

It is estimated that the run-off from about 400 square miles in addition to the 500 square miles drained by the Mimbres River, Lampbright Draw, and Cameron Creek contributes to the groundwater supply of the Mimbres Valley. This additional area comprises the mountains back of Silver City and Santa Rita, the northwest and south slopes of the Cooks Range, and the foothills and steeper parts of the valley floor at the upper end of the valley. According to the records the rate of run-off from a square mile of the drainage basins of Lampbright Draw and Cameron Creek does not differ greatly from that from a square mile of the main Mimbres drainage basin in corresponding years.

For purposes of computation it is assumed that the average rates of run-off from these three drainage areas are equal and that the average rate of run-off from the additional 400 square miles referred to is half as great. On this basis the observed 20-year discharge of the Mimbres River plus the estimated underflow is made applicable to the entire 900 square miles, and the total stream discharge from which the ground water of the valley is chiefly derived is computed as follows:

Estimated stream discharge into Mimbres Valley from which the ground water is chiefly supplied:

\begin{tabular}{|c|c|c|}
\hline Period & $\begin{array}{l}\text { Number } \\
\text { of years }\end{array}$ & $\begin{array}{c}\text { Average } \\
\text { annual } \\
\text { discharge } \\
\text { (acre-feet) }\end{array}$ \\
\hline $\begin{array}{l}1908-1928 \\
1914-1916,1910,1912-13,1917-1928\end{array}$ & $\begin{array}{r}20 \\
3 \\
17\end{array}$ & $\begin{array}{l}26,700 \\
85,700 \\
16,300\end{array}$ \\
\hline
\end{tabular}




\section{FACILITIES FOR GROUND-WATER INTAKE}

Considerable attention has been given during the investigation to studies of the permeability of the soils of the valley and of the streambed gravel, sand, and clay, with the object of obtaining information as to the facility of these materials for taking in water. Penetration by rainfall has been studied, and observations have been made of the rate at which storm waters sink in borrow pits and in trenches along the roadside. Cylinders were driven into the normal bed of the Mimbres River and into the soils of adjacent areas over which the river spreads during periods of high discharge, and later tests were made of the rate at which the water would penetrate into the inclosed soil columns.

It was found that water under a small head percolated downward very rapidly in river-bed gravel and sand-so rapidly, in fact, that attempts to compute the rate of movement were unsuccessful. Percolation was also rapid in the sandy soils, a depth of a foot or more of water disappearing in such soils in a day. The rate of downward movement in the cemented gravel underlying the bench at the north end of the valley is slow, observed rates of subsidence of storm waters in gravel pits in these materials ranging from 2 to 5 inches a day. Observed depths of water penetrating clay or clay loam in natural depressions and in borrow pits under a head of 6 inches to a foot ranged from half an inch to 4 inches a day. In silty soils the movement was found to be much slower, observed rates of penetration under a head of 1 foot ranging from a small fraction of an inch to an inch daily.

At the upper end of the valley the normal and flood channels of the Mimbres River and other large streamways consist in great part of gravel and boulder beds which are highly permeable and take in water with great rapidity. The bed of the Mimbres River below Spalding consists of gravel and sand, much finer than the gravel and boulders of the upper river and not nearly so permeable, although they take in water with considerable readiness. The high boulder-strewn alluvial slopes adjacent to the Cooks Range and the Florida Mountains are well adapted for ground-water intake, but the portion of these slopes underlain by coarse materials is not over a mile or two in width. Once the streams are across this narrow belt the opportunities for the water to penetrate to any considerable depth are not good, the middle and lower portions of the alluvial slopes as well as the lowlands at the foot of these slopes being underlain in most places by comparatively impervious clay loam and silt. The surface gravel of the plain at the upper end of the valley, as has been stated, is more or less cemented and takes in water slowly. In wet years, however, local precipitation and run-off may penetrate in moderate quantities $3030^{\circ}-31-6$ 
to the water table through this gravel. San Vicente Arroyo delivers the run-off from about 200 square miles to the Mimbres. In its upper reaches the beds of this arroyo and its tributaries consist of boulders, gravel, and sand, which are favorable for ground-water intake. From a point near Whitewater (see pl. 1) downstream to its junction with the Mimbres the arroyo is largely in clay loam and silt that are only slightly permeable. Moreover, the water that reaches the lowermost few miles of the arroyo is diverted and spread over pasture lands, where it is largely dissipated by transpiration of the grasses and by evaporation. The water that reaches the lower part of the Mimbres River below the bridge 6 miles east of Deming is largely spread over a rather wide expanse of valley land. During the growing season ordinary runs of water, up to about 75 second-feet are diverted through the Wamel Canal at a point about 2 miles southwest of Black Mountain (see pl. 1) and used for the irrigation of pasture land and a small area of cultivated land northwest and west of Deming. Downstream from a point about 8 miles east of Deming the channel of the river becomes small, and still farther on, near the north point of the Florida Mountains, it disappears entirely. As there is nothing to restrain the water in these localities the floods spread out over the valley in shallow sheets, the area covered depending upon the amount of water brought down by the floods. In general neither the areas served by the Wamel Canal nor the lands subject to inundation on the lower reaches of the stream north and east of the Florida Mountains offer very favorable facilities for groundwater intake, especially if the periods of flooding are brief. Small portions of the flood lands are underlain by surface gravel and sand that offer an opportunity for the ingress of water, but most of the surface of these areas is underlain by clay loam and silt of considerable depth. If the floods persist for a long time considerable groundwater recharge may occur in these areas. If the floods are short the recharge is likely to be small or none.

\section{QUANTITY OF INTAKE}

The studies of the intake of ground water have been devoted chiefly to a consideration of seepage losses from the Mimbres River. Several runs of water were followed from the mountains down to the locality of Deming, and current-meter measurements were made every few miles to determine the rate of loss by seepage in different stretches of the stream. The floods generally rise with great rapidity, nearly always during the night. The crest is usually reached within an hour, as shown by the automatic water-stage recorder at the Faywood gaging station, and almost immediately thereafter the stage. begins to decline. Under such conditions any data which it is possible to obtain concerning loss of flow in a particular stretch of the streams 
are subject to considerable error. If the stream gager moves downstream at a more rapid rate than the average rate of stream flow his estimate of seepage losses is likely to be too small; if he moves at a slower rate his estimate is likely to be too large.

Results based on six sets of measurements in 1928 and 1929 indicate that for moderate runs ( 75 to 125 second-feet at Faywood gaging station) the losses by seepage run from $4 \frac{1}{2}$ per cent to the mile downward. The results differ considerably for different sets of observations, the percentage of loss usually but not always varying inversely with the amount of discharge. Average figures computed from the measurements are approximately as follows: Foothills to mouth of San Vicente Arroyo, 35 per cent; mouth of San Vicente Arroyo to intake of Wamel Canal, 25 per cent; intake of Wamel Canal to bridge 6 miles due east of Deming, 25 per cent. The indicated percentage of loss is that of the flow entering each stretch-that is, a discharge of 100 second-feet at the Faywood gaging station declines to about 65 second-feet at the mouth of San Vicente Arroyo, to about 49 second-feet at the intake of the Wamel Canal, and to about 36 second-feet at the bridge 6 miles east of Deming. Practically all the measurements were taken during floods, when the water was heavily laden with sand and silt. This is the normal condition of the water, at least during the summer. Only one set of measurements of fairly clear water was made. This was on August 29, 1929, following about three weeks of continuous runs during which the water had cleared up considerably. On that date a discharge of 40 second-feet disappeared entirely in the section between the gaging station and a point about 3 miles south of the mouth of San Vicente Arroyo. This rate of loss was materially higher than occurred at other times when the water was muddy. As previously stated, the stream discharge during moderate floods is usually diverted into the Wamel Canal, and only occasionally is the water allowed to flow downstream to the locality of Deming. However, when the discharge of the river at the canal intake becomes much greater than 75 second-feet, a part of it is allowed to pass the head gate of the canal and to continue on downstream.

The amount of seepage loss is proportional to the area wetted by the stream, the length of time the wetted area is submerged, and the depth of water in the stream. The velocity of the stream is proportional to its discharge. At the Deming bridge small runs of water have velocities ranging from 2 to 3 feet a second, whereas large floods have velocities that are much greater. For example, the flood of August 10, 1929, at its highest stage (approximately 2,000 cubic feet a second), had a velocity of about 8 feet a second. No attempts have been made to estimate seepage losses below the bridge 6 miles east of Deming. Some water from moderate runs and even from 
small runs flows as far downstream as the El Paso road in the Miesse district, but the water seldom crosses the road in any considerable quantity. Early in September, 1925, a flood submerged the road and continued down the valley for many miles. This did not occur again until August 10, 1929. Therefore, proportionately much less water sinks into the sand and gravel of the river bed during periods of high flood than during small or moderate runs. During large floods there is so much sand and silt in suspension and the channel is so constantly changing that it is impossible to obtain accurate determinations of the discharge of water or of the seepage losses.

A part of the water lost in the bed of the stream goes to fill the pores in the sand and gravel. These materials are depleted of moisture during the long dry seasons and to some extent also between successive floods in the rainy season. The amount of depletion, however, as estimated from moisture determinations by the writer, is not great.

In winter the water tends to be clearer than in summer, less water is diverted, and evaporation losses are small. Moderate continuous runs of water during the winter and spring, therefore, contribute proportionally most heavily to ground-water intake. Most of the large floods occur in summer, and much of the water of these floods is dissipated by evaporation and transpiration from submerged areas and irrigated lands.

Although the data manifestly are fragmentary and incomplete, it is believed that some tentative estimate of the intake of ground water to the Mimbres Valley should be made at this time. On page 76 the stream discharge, which is believed to be the source of practically all the ground-water recharge, is computed as averaging 26,700 acre-feet a year during 20 years. After careful consideration of the daily records at the Faywood gaging station for 20 years and of the data obtained in 1928 and 1929 on the facilities for ground-water intake the annual recharge is estimated in terms of a percentage of the stream discharge as follows: Wet years 1914-1916, 30 per cent; remainder of period of record, 50 per cent; mean average for 20 years, approximately 40 per cent. On this basis the average annual increment to the ground-water supply of the Mimbres Valley during 20 years was between 10,000 and 11,000 acre-feet a year.

\section{SHAPE OF WATER TABLE AND MOVEMENT OF GROUND WATER}

Lines of levels aggregating about 250 miles in length have been run to determine the altitude of the water level in about 200 wells, and from these figures a contour map of the water table has been compiled covering the ground-water areas with which this report is chiefly concerned. Some additional leveling in localities 15 to 20 miles south of 
Deming still remains to be done. This map, which will be submitted in completed form in the final report, gives information as to the direction of the slope of the water table and therefore as to the direction in which the ground water is moving. It also shows the hydraulic gradient, or rate of slope of the water table in each locality. This is important, because the rate of flow of the ground water depends on the hydraulic gradient as well as on the permeability and thickness of the water-bearing bed. It is found that nearly everywhere in the valley the ground water is moving northwest to southeast. From Black Mountain down to the east and south limits of the pumping area the slope of the water table ranges from 10 to 15 feet to the mile and averages about 13 feet. Above Black Mountain the slope is steeper; in the locality of Spalding it ranges from 25 to 35 feet to the mile.

If in a locality in which considerable pumping is done the pumping produces a depression or even a flattening of the water table that persists throughout the year, it may be inferred that little or no water is moving down the valley past the pumps in that particular locality. If no permanent depression or flattening occurs, it must be inferred that some of the ground water percolates through the locality and escapes in the direction of the slope of the water table. The leveling has disclosed that a depression of the water table has been developed in a part of the Miesse district but not in other parts of the pumping area. It is believed, therefore, that except perhaps in a part of the Miesse district, the pumps are not recovering all the underflow but that some ground water is escaping toward the south each year.

A study is being made of the natural rate of the flow of the ground water. For this purpose a method is being used which was developed by Dr. Thiem, of Germany, and which may be called the pumping method of determining permeability. Three wells are required to make a test by this method. One of the wells is pumped at a measured rate for several hours, and observations are made as to the resulting drawdown in the other two wells. The natural rate of flow can then be computed by means of a mathematical formula. Tests of this kind have been made at the Gaskell, Cleary, Rutland, and Ernst farms and at the Chinese Gardens, and additional tests are to be made next summer. Observation wells have recently been put down on the Williams and Russell farms, and additional wells will be put down if necessary. Computations based on observations made thus far show a rate of natural ground-water movement averaging between 2 and 3 feet a day.

\section{FLUCTUATIONS IN GROUND-WATER LEVEL}

All available sources of information have been consulted in the effort to obtain accurate figures on the amount of water-table fluctuation 
which has occurred since pumping began on a large scale. The few pumping-plant owners whose activities began in the early days of pumping have been interviewed. The large volumes of data concerning water-table altitudes in 1914 given by N. H. Darton in United States Geological Survey Bulletin 618 and in the records of pumping tests made by the State engineer's office have been consulted. These records show the water levels in 1914 in many wells that are still in existence.

It is found that practically everywhere in the valley the water level has declined. Since 1914 the decline under an area of about 100,000 acres west, south, and east of Deming has ranged from about 4 to 8 feet and has averaged about 6 feet. Within the city of Deming the decline in the same period has amounted to about 10 feet, and in the heavily pumped portion of the Miesse district it has averaged not less than 15 feet. Wells that are close to the Mimbres River east of Deming show the smallest decline. These wells, according to their owners, are subject to a pronounced rise following long-continued runs of water in the lower Mimbres.

In general wells at a considerable distance from the river have failed to develop much of a rise in recent years, but after the wet years 1914 to 1916 the water levels rose materially in a number of such wells. Two instances are reported of a rise in wells at some distance from the river after the flood of late August and early September, 1925. Mr. Wasdin reported that in his well west of Deming (No. 90a, pl. 1) the water level rose about 3 feet after this flood. Mr. J. E. Hestand reported that in his well (160b), in the southeast corner of the Miesse district, the water level rose an appreciable amount after the flood. Mr. J. N. Cobb reported that in his well (44a) about three-quarters of a mile east of the courthouse at Deming, the water level has gone down about 7 feet since the well was sunk in 1912, as disclosed by a long series of careful observations. He states that the decline has been gradual but persistent. After the wet years 1914 and 1915 the water level rose somewhat and for two years was higher each spring than it had been the spring preceding. Throughout the rest of the period, however, there has been a gradual decline from year to year. The water rises each winter but invariably fails to come back to the level of the preceding spring. A similar gradual but persistent decline has been noted in the Bowman (104), Holiday (137), J. B. Anderson (169a), Smyer (147), Hatfield (144), and other wells.

Records of water levels obtained during the last two years show that the decline is still in progress. A large number of measurements have been made, but it is not within the scope of this preliminary report to analyze all these data, and, indeed, a longer record should be obtained before a detailed analysis of water-level fluctuations is attempted. The most accurate information as to the net rise or 
decline of the water table can be obtained by comparing the water levels of late winter or early spring in successive years. Such data are thus far available only for the original group of observation wells selected by Mr. Fiedler in the fall of 1927, of which 11 are pumped for irrigation in summer and 13 are unused. Records of water level in these wells on January 30-31, 1928, and February 3-4, 1929, are given in the following table. The location of the wells is shown on the map.

Midwinter depths to water in a part of Mimbres Valley observation wells, 1928 and 1929

\begin{tabular}{|c|c|c|c|c|}
\hline No. & Name & $\underset{1928}{\text { Jan. 30-31, }}$ & $\begin{array}{c}\text { Feb. 3-4, } \\
1929\end{array}$ & $\begin{array}{l}\text { Decline or } \\
\text { rise in water } \\
\text { level (feet) }\end{array}$ \\
\hline $\begin{array}{r}29 \\
a \quad 70 \\
a \quad 93 \\
a \quad 111 \\
123 \\
166 \\
180 \\
190 \\
a \quad 174 \\
179 \\
108 \\
107 \\
a \quad 104 \\
88 \\
a \quad 40 \\
a \quad 50 \\
a \quad 52 \\
\text { a } 58 \\
\text { a } 59 \\
134 \\
\text { a } 149 \\
154 \\
155 \\
156\end{array}$ & 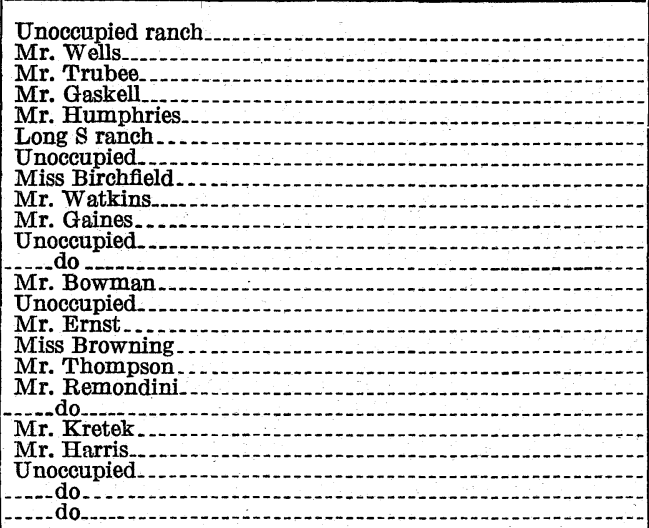 & $\begin{array}{r}77.35 \\
62.65 \\
60.83 \\
60.44 \\
56.73 \\
48.61 \\
55.92 \\
23.16 \\
42.26 \\
44.42 \\
46.16 \\
16.58 \\
\mathbf{b} 4.63 \\
53.34 \\
50.45 \\
31.14 \\
29.47 \\
25.11 \\
24.80 \\
12.36 \\
67.45 \\
57.87 \\
57.92 \\
65.40\end{array}$ & $\begin{array}{l}79.99 \\
64.59 \\
61.83 \\
61.27 \\
57.90 \\
48.49 \\
56.08 \\
23.20 \\
42.57 \\
44.77 \\
46.34 \\
17.82 \\
47.80 \\
53.59 \\
51.21 \\
31.42 \\
29.74 \\
25.05 \\
24.76 \\
12.57 \\
69.62 \\
58.29 \\
58.26 \\
66.57\end{array}$ & $\begin{array}{r}.64 \\
-2.64 \\
-1.94 \\
-1.00 \\
-.83 \\
-1.17 \\
+.12 \\
-.16 \\
-.04 \\
-.31 \\
-.35 \\
-.18 \\
-1.24 \\
-.17 \\
-.25 \\
-.76 \\
-.28 \\
-.27 \\
+.06 \\
+.04 \\
-.21 \\
-2.17 \\
-.42 \\
-.34 \\
-1.17\end{array}$ \\
\hline
\end{tabular}

- Pumped for irrigation during summer.

b Feb. 21, 1928.

In three of the wells the water level was slightly higher in 1929 than in 1928. In the remaining wells, however, the water level was lower in 1929, the average net decline for the year being 0.75 foot, or 9 inches. The greatest decline took place in the areas of heaviest pumping or on the borders of these areas. In all these wells, except Nos. 29 and 166, the water level rose somewhat during the winter, the average rise being 7.8 inches during the winter of $1927-28$ and 8.8 inches during the winter of 1928-29. The average rise in the pumped wells during the winter of 1928-29 was 13.08 inches; that in the unused wells was 4.68 inches. Well 29 showed a decline of 12 inches during the winter of 1927-28 and a decline of 13 inches during the winter of 1928-29. Well 166 dropped about 1 inch both winters.

About 150 wells are now under observation. These wells are widely spaced over the valley with a view to obtaining representative figures on fluctuation of the water table, both in areas that are probably affected by ground-water intake and in areas that are known to 
be affected by ground-water discharge. The period of record of all the wells except those listed in the table on page 83 is only a little more than a year and is therefore still too short to serve as a basis for any very definite conclusions. Briefly, the figures obtained show that practically everywhere in the valley the water level was lower August 1, 1929, than it was August 1, 1928. This condition prevailed alike in pumped areas, in areas of ground-water intake, and in the intermediate or conduit areas. The cause of the decline was everywhere the same: The outflow or discharge of ground water was greater than the inflow or recharge. In the pumping districts the discharge is effected partly by pumping and partly by natural outflow. Elsewhere both recharge and discharge occur chiefly by natural underflow, the rate of which is determined by the hydraulic gradient, or slope of the water table, and the thickness and permeability of the waterbearing beds.

The amount of drawdown in pumped wells varies to a certain degree with the length of time the well is pumped and with the amount of pumping activity in the immediate vicinity. If pumping is temporarily discontinued the water rises rapidly for a few hours and very slowly thereafter, the amount and rate of rise being more or less affected by pumping in near-by wells. Under such circumstances records of water levels obtained from the pumping-plant wells during the irrigation season have little value as a basis for estimating annual fluctuations, and no particular effort has been made to obtain such records. Records of summer fluctuations of water level in unused wells in the pumping districts, however, have value, particularly if the wells are as much as half a mile from any pumped well. Records obtained from a few wells of this kind indicate that between August 1, 1928, and August 1, 1929, the water level declined on the average about 9 inches in the heavily pumped localities and only about 2 inches in the lightly pumped localities.

A pronounced decline of the water table also took place in the areas of intake, far from the pumping districts. For example, from August 1, 1928, to August 1, 1929, the water level declined 4 to 6 inches in areas near San Vicente Arroyo or Silver City Draw, 2 miles west of Spalding (wells 5 and 6 ). Well 4 , a quarter of a mile from the Mimbres River, on the old Jacobson ranch, about 3 miles northeast of Spalding, showed a decline of about 7 feet for the year. Wells 11 to 15 on the Spalding tract, comprising 6,000 acres near Spalding camp, showed declines of 1.9 to 3.5 feet during the year, the wells nearest to the river showing the greatest decline. Well 2 (unused) of the Peru Smelting Co. (map No. 21), about 350 feet from the Mimbres River, $31 / 2$ miles northwest of Deming, showed a decline of 6 inches during the year. The ground waters in the locality of this unused well may be somewhat affected by pumping. Elsewhere in the areas 
of intake above referred to the decline in water level was the result of natural conditions, the rate of down-valley movement or outflow being greater than the rate of inflow or recharge. The decline, in fact, was a manifestation of intermittent recharge. During the winter of 1926-27 the river flowed to the locality of Black Mountain and farther almost continuously for several months, and seepage losses therefrom raised the water table to comparatively high levels in areas closely adjacent to the stream. From the spring of 1927 to the later part of July, 1929, the surface discharge was small, there was no great amount of ground-water recharge, and the ground-water level showed a continuous decline in stage. A few short runs in the river during the summer of 1928 provided only enough ground-water recharge to raise the water table temporarily in localities close to the river and slightly retard the rate of water-table decline in areas farther away. Floods during late July and August, 1929, the largest in several years, caused a general rise of the water table in areas of intake at the upper end of the valley. Early in October, 1929, the water level in wells close to San Vicente Arroyo had risen a few inches, wells close to the Mimbres River on the Jacobson ranch and Spalding tract had risen several feet, and wells on the Spalding tract as far as 3 miles from the river had risen at a rate which seemed to promise a return to the levels of August 1, 1928, if not to higher levels. In the valley near Deming the floods of late July and August, 1929 , were followed by a considerable rise in water level in several wells that are within 2,000 feet or so from the river, but wells at greater distances showed no evidence of rise at the end of the field season, early in October.

In most of the wells in the intermediate or conduit belt the water level declined only a few inches between August 1, 1928, and August 1, 1929. In well 29 (see table), however, the water level declined 2.57 feet from August 1, 1928, to June 9, 1929, and a few days later the water level had declined so low that the recorder float would no longer operate. This well is about 2 miles northwest of the north boundary of the heavily pumped district west of Deming. It was measured by Mr. Fiedler in 1927 and was continuously equipped with an automatic water-stage recorder from September 27, 1927, until June 15, 1929. This record shows a slight rise from October 29 to November 15, 1927. During the remainder of the period the water level declined persistently, the net decline in about $20 \frac{1}{2}$ months amounting to 4.96 feet. It may be that the decline in this well is due in part to the same reason that caused the wells in the Spalding tract to show a decline - that is, intermittent recharge. If so, it was to be expected that a marked rise would occur in the well during the winter of 1929-30, as a result of the floods of July and August, 1929. 


\section{PUMPAGE AND NATURAL DISCHARGE OF GROUND WATER}

So far as has been learned none of the irrigators in the Mimbres Valley have kept accurate long-time records of the amount of water they have pumped. Partial records have been obtained from some of the farmers, and a considerable volume of data in the files of the Deming Ice \& Electric Co. has been consulted. On the basis of this information it is estimated that the average depth of water used in irrigation is about 20 inches a year and that the present annual consumption of water, including supplies used for domestic and industrial purposes, amounts to about 10,500 acre-feet. No one knows how much water was used in former years. During the boom years 1914 to 1917 the annual pumpage may have been more than twice as great as at present, but during the slump years 1918 to 1923 the annual average was probably less than half as great as at present. The mean annual pumpage since 1914 has almost certainly not exceeded 10,000 acre-feet.

Before pumping was begun a state of equilibrium existed in the ground-water conditions, the average annual inflow being balanced by an equivalent average outflow or discharge. The inflow then as now was contributed chiefly by seepage from the Mimbres River and its tributaries. Discharge took place by percolation southward and eastward out of the valley and by evaporation from the soil and transpiration from plants. This balance was a delicate one and was easily subject to disturbance.

The chief effect of pumping has been to cause additional discharge without substantially reducing the natural discharge or increasing the recharge. Losses by evaporation have been eliminated since the decline of the water table, but the area formerly subject to loss by evaporation was small, and the saving thus effected has been meager. Losses continue by transpiration in the areas of shallow ground water. The mesquite in the Mohave Desert in California is known to send its roots to a depth of 40 feet to obtain ground water, and the mesquite in the Mimbres Valley may possibly be absorbing some ground water where the depth is even greater. Mesquite roots were traced to a depth of 41 feet in a test well put down by the writer on a tract of land about $1 \frac{1}{2}$ miles southeast of Deming belonging to the city. Water was encountered in this well at 48.5 feet.

The lowering of the water table resulting from pumping has slightly increased the hydraulic gradient toward the pumping areas, but in general terms the increase is so slight that the rate of inflow into these areas is probably only a little more rapid than it was before pumping began. A part of the underflow is diverted toward the pumps during the irrigation season, and some is diverted during the winter to fill up the depressions caused by pumping. In most of the pumping 
areas only a slight depression is formed in the water table during the pumping season, and this depression is almost completely smoothed out during the winter. In parts of the Miesse district the depression produced by pumping is somewhat deeper and is only partly filled during the winter. From this it is concluded that natural outflow continues to a degree, except perhaps in parts of the Miesse district, and that the existing pumps are not intercepting all the underflow. To accomplish this fully, however, would require a lowering of the water table below the limits of the economic pumping lift.

\section{FLUCTUATIONS IN STORAGE OF GROUND WATER}

Changes of considerable magnitude in ground-water storage have taken place since pumping was begun on a large scale. It is estimated that fully 500,000 acre-feet of valley fill, consisting of gravel, sand, silt, loam, and clay loam in varying proportions, was unwatered as a result of the decline of the water table in the 15-year period ending in 1929. It is further estimated that about 25,000 acre-feet of valley fill became saturated in each of the winters of 1927 and 1928, as a result of the rise of the water table, but that the net unwatering from August 1, 1928, to August 1, 1929, amounted to about 30,000 acre-feet of valley fill.

In order to compute the amount of water drained from the zone or belt of water-table decline it is necessary to assume some figure for the specific yield of the materials in which the decline took place. The specific yield may be defined as the ratio of the volume of water that will drain by gravity from a given water-bearing material to the volume of the material drained.

The interstices in sand and gravel are comparatively large, and consequently the effect of molecular attraction in them tending to resist the pull of gravity is comparatively slight. Therefore a large part of the water which they contain in a saturated condition drains out as the water table declines. In other words, their specific yield is high. The pore spaces in silt and clay loams are very small, and therefore the effect of molecular attraction in them is correspondingly great. These materials therefore retain a much higher proportion of water as the water table declines than is retained by sand and gravel. Moreover, the process of drainage in fine materials continues for a long time, although at a greatly reduced rate. Experiments by the writer in Escalante Valley, Utah, showed that during periods ranging from 12 hours to several days fine-textured soils such as silt and clay loams yield a volume of water ranging from less than 0.5 per cent to 8 per cent and averaging about 3 per cent of the volume of material drained. With the passing of many months or years the clay and silt probably continue to lose water, but not much is known on this subject. 
Studies were made of the specific yield of materials of this character in the unwatered zone in a well recently put down at the Chinese Gardens, 1 mile east of Deming; in test holes put down by the writer in a tract $1 \frac{1}{2}$ miles southeast of Deming belonging to the city; and at the Williams farm, 9 miles southeast of Deming. It is estimated from these studies that at different depths in the unwatered zone the volume of water that drained out ranged from 8 to 14 per cent of the volume of material drained. In order to have a basis for computation it will be assumed that the unwatered silt and clay loams in the pumping districts of the Mimbres Valley have parted with a volume of water representing 10 per cent of the volume unwatered and that the unwatered sand and gravel have yielded 20 per cent of their volume. From studies of the logs of 100 or more widely spaced wells in the pumping districts it is computed that 75 per cent of the drained materials consist of silt and clay loams and 25 per cent of sand and gravel. This computation leads to the conclusion that the volume of water drained from the unwatered zone amounted to $12 \frac{1}{2}$ per cent of the volume of material drained. The ratio of the volume of water required to refill the partly emptied pore spaces to the volume of material resaturated with the rise of the water table each winter is a somewhat smaller figure, because the pores have had only a few months to drain as compared with several years of continuous drainage from materials that were unwatered early in the pumping development. This ratio is assumed to be 10 per cent.

If the ground-water storage in the pumping districts was reduced during the 15-year period ending in 1929 by 12 per cent of 500,000 acre-feet, or 60,000 acre-feet, it follows that 40 per cent of the water pumped from the Mimbres Valley during this period was taken from storage. If the increase in storage in the pumping districts during each of the two winters covered by the investigation (1927-28 and 1928-29) amounted to 10 per cent of 25,000 acre-feet, and the pumpage during each winter is assumed to be 500 acre-feet, the average winter recharge of these districts amounted to about 3,000 acre-feet. If there was an equal amount of recharge during the summers, the average annual recharge of the pumping districts in the last two years has amounted to about 6,000 acre-feet. This is somewhat less than the estimated long-term average annual intake into the entire underground reservoir of the Mimbres Valley. Although the yearly intake of ground water varies within wide limits, the rate of movement through the water-bearing materials between the intake and pumping areas and therefore the yearly delivery of water through this underground conduit is more nearly constant. 


\section{CONCLUSIONS AND RECOMMENDATIONS}

Practically all the fundamental facts disclosed by the present investigation have been considered in the preparation of this preliminary report, but the detailed observations have covered only a little more than a year, and it is therefore too early to arrive at final conclusions. The investigation, however, indicates that the present irrigators in the Mimbres Valley are reasonably secure in their water supply provided no large additional pumping developments are made. The quantity of water stored in the underground reservoir is very large, but the annual recharge of this reservoir is relatively small. In the 15 years since pumping began the water table has declined 2 to 15 feet in different parts of the pumping districts, the average decline being about 6 feet. This decline represents no particularly unfavorable condition, for a certain amount of decline in water levels is an inherent and unavoidable consequence of any ground-water development. The present rate of pumping will entail further decline, but it should occur at a decreasing rate and may to a large extent be offset by rise in years of heavy rainfall.

In view of the indications of the data now available, it would be unwise to formulate plans at this time for any large additional pumping development. Detailed observations are to be continued for at least two years, and arrangements should be made to have measurements of water levels in some of the observation wells made at regular intervals by State or local agencies for several years thereafter. If these observations should show unexpectedly large recharge it will then be time for contemplating additional development of magnitude.

A small amount of additional development in areas now lightly pumped could be attempted with reasonable safety, and thereby some of the water that would otherwise escape from the valley by underflow would be salvaged. No additional developments should be permitted at this time in the most heavily pumped localities.

Only a few deep wells have been drilled in the valley. These wells have a relatively high head and seem to show that another waterbearing bed lies below those from which the present irrigation supply is obtained and is separated from them by a more or less effective confining bed. This deeper bed may contain a moderate reserve supply that could be developed in the event that the water in some of the existing pumped wells should fall below the economic pumping lift. No information is available as to whether this deeper bed would yield freely enough to be of practical value for irrigation, but it may be a significant fact that all these deeper wells have been abandoned. Moreover, it can not be safely assumed that the water in the deeper bed is completely isolated from that in the shallow beds. 
The intake from the Mimbres River could be artificially increased by temporary storage of the flood water in a surface reservoir and gradual release of this water, but this plan would require the construction of an expensive dam. This phase of the subject will be further considered in the final report.

In 1927 the State legislature of New Mexico enacted a law ${ }^{3}$ which declared that waters in underground streams, channels, artesian basins, reservoirs, and lakes belong to the public and are subject to appropriation for beneficial use. The State supreme court, in a decision ${ }^{4}$ rendered in April, 1929, upheld the principle of this law but declared the law itself unconstitutional on account of certain technicalities. If this law is reenacted by the next legislature, with the unconstitutional features removed, the irrigators in the Mimbres Valley should, under its provisions, form a ground-water district and file applications for the appropriation of ground water. The granting of such requests will give them definite water rights and will protect them in the use of such waters.

${ }^{8}$ New Mexico State Legislature, 8th sess., ch. 182, H. B. 314, approved March 16, 1927.

4 Yeo $v$. Tweedy and Yeo $v$. Pearson; Supreme court of New Mexico, January term, 1929. 